\title{
Denitrification by sulfur-oxidizing bacteria in a eutrophic lake
}

\author{
Amy J. Burgin ${ }^{1,2,3, *}$, Stephen K. Hamilton ${ }^{1,2}$, Stuart E. Jones ${ }^{1,4}$, Jay T. Lennon ${ }^{1,5,6}$ \\ ${ }^{1}$ W. K. Kellogg Biological Station, ${ }^{2}$ Department of Zoology and ${ }^{5}$ Department of Microbiology and Molecular Genetics, \\ Michigan State University, 3700 East Gull Lake Dr., Hickory Corners, Michigan 49060, USA \\ ${ }^{3}$ Present address: School of Natural Resources, University of Nebraska-Lincoln, 3310 Holdredge St., 412 Hardin Hall, \\ Lincoln, Nebraska 68583-0974, USA \\ ${ }^{4}$ Present address: Department of Biological Sciences, University of Notre Dame, 264 Galvin Hall, Notre Dame, Indiana 46556, \\ USA \\ ${ }^{6}$ Present address: Department of Biology, Indiana University, 1001 E. 3rd St., Bloomington, Indiana 47405-3700, USA
}

\begin{abstract}
Understanding the mechanistic controls of microbial denitrification is of central importance to both environmental microbiology and ecosystem ecology. Loss of nitrate $\left(\mathrm{NO}_{3}^{-}\right)$is often attributed to carbon-driven (heterotrophic) denitrification. However, denitrification can also be coupled to sulfur (S) oxidation by chemolithoautotrophic bacteria. In the present study, we used an in situ stable isotope $\left({ }^{15} \mathrm{NO}_{3}{ }^{-}\right)$tracer addition in combination with molecular approaches to understand the contribution of sulfur-oxidizing bacteria to the reduction of $\mathrm{NO}_{3}{ }^{-}$in a eutrophic lake. Samples were incubated across a total dissolved sulfide $\left(\mathrm{H}_{2} \mathrm{~S}\right)$ gradient ( 2 to $\left.95 \mu \mathrm{M}\right)$ between the lower epilimnion and the upper hypolimnion. Denitrification rates were low at the top of the chemocline $(4.5 \mathrm{~m})$ but increased in the deeper waters $(5.0$ and $5.5 \mathrm{~m})$, where $\mathrm{H}_{2} \mathrm{~S}$ was abundant. Concomitant with increased denitrification at depths with high sulfide was the production of sulfate $\left(\mathrm{SO}_{4}{ }^{2-}\right)$, suggesting that the added $\mathrm{NO}_{3}{ }^{-}$was used to oxidize $\mathrm{H}_{2} \mathrm{~S}$ to $\mathrm{SO}_{4}{ }^{2-}$. Alternative nitrate removal pathways, including dissimilatory nitrate reduction to ammonium (DNRA) and anaerobic ammonium oxidation (anammox), did not systematically change with depth and accounted for 1 to $15 \%$ of the overall nitrate loss. Quantitative PCR revealed that bacteria of the Sulfurimonas genus that are known denitrifiers increased in abundance in response to $\mathrm{NO}_{3}{ }^{-}$addition in the treatments with higher $\mathrm{H}_{2} \mathrm{~S}$. Stoichiometric estimates suggest that $\mathrm{H}_{2} \mathrm{~S}$ oxidation accounted for more than half of the denitrification at the depth with the highest sulfide concentration. The present study provides evidence that microbial coupling of $\mathrm{S}$ and nitrogen $(\mathrm{N})$ cycling is likely to be important in eutrophic freshwater ecosystems.
\end{abstract}

KEY WORDS: Denitrification · Nitrate reduction - Sulfur oxidation · Sulfur-driven denitrification · Sulfurimonas denitrificans $\cdot$ Sulfide $\cdot$ Wintergreen Lake

\section{INTRODUCTION}

Denitrification is an important microbial process with beneficial consequences for water quality. More than $75 \%$ of the anthropogenic nitrogen $(\mathrm{N})$ entering watersheds is lost along landscape flow paths before reaching the oceans (Alexander et al. 2000). This 'missing' $\mathrm{N}$ is attributed to heterotrophic denitrifica- tion, an anaerobic microbial process that couples the oxidation of organic matter with the reduction of nitrate $\left(\mathrm{NO}_{3}{ }^{-}\right)$to gaseous $\mathrm{N}_{2}$. Little is known, however, about where and how this $\mathrm{N}$ removal takes place (Seitzinger et al. 2006, Burgin \& Hamilton 2007). Due to long water residence times and high biological activity, lakes and reservoirs may be important, yet overlooked, sites for N removal (Saunders \& Kalff 2001). 
Anaerobic sediments and biofilms of aquatic ecosystems are conducive to $\mathrm{NO}_{3}{ }^{-}$reduction; however, ${ }^{15} \mathrm{~N}$ tracer studies often show that less than half of the total $\mathrm{NO}_{3}{ }^{-}$disappearance is attributable to direct denitrification (e.g. Mulholland et al. 2008). Such findings suggest that other microbial processes may be important for removing $\mathrm{NO}_{3}{ }^{-}$in freshwater ecosystems (Gardner et al. 2006, Burgin \& Hamilton 2007, Scott et al. 2008, Gardner \& McCarthy 2009). $\mathrm{NO}_{3}{ }^{-}$can also be reduced via dissimilatory nitrate reduction (DNRA) to ammonium $\left(\mathrm{NH}_{4}{ }^{+}\right)$by fermentative bacteria as well as via denitrification or DNRA coupled to the chemolithoautotrophic oxidation of either sulfur (Brunet \& Garcia-Gil 1996, Otte et al. 1999) or iron (Weber et al. 2006). The relative importance of DNRA and denitrification is germane to understanding the fate of $\mathrm{NO}_{3}{ }^{-}$because the $\mathrm{NH}_{4}{ }^{+}$ produced by DNRA is biologically available, while $\mathrm{N}_{2}$, the predominant end-product of denitrification, is lost from the available $\mathrm{N}$ pool.

Anaerobic oxidation of ammonium (anammox) also converts $\mathrm{NO}_{3}{ }^{-}$to $\mathrm{N}_{2}$. This chemolithoautotrophic pathway reduces nitrite $\left(\mathrm{NO}_{2}^{-}\right)$(the source of which is presumably incomplete denitrification of $\mathrm{NO}_{3}{ }^{-}$) with electrons from $\mathrm{NH}_{4}{ }^{+}$to produce $\mathrm{N}_{2}$. Anammox can account for high fractions $(\sim 50 \%)$ of $\mathrm{N}_{2}$ production in marine oxygen-minimum zones (Dalsgaard et al. 2005). Few estimates of anammox exist for lakes, but when measured in Lake Tanganyika, anammox contributed $<13 \%$ of the overall $\mathrm{N}_{2}$ production in a suboxic layer at 100 to $110 \mathrm{~m}$ depth (Schubert et al. 2006).

The various dissimilatory $\mathrm{N}$ transformations are subject to different controlling factors (Burgin \& Hamilton 2007). Denitrification is known to be influenced by the availability of labile organic carbon $(\mathrm{C}), \mathrm{NO}_{3}{ }^{-}$, and $\mathrm{O}_{2}$ (Cornwell et al. 1999). In addition, $\mathrm{H}_{2} \mathrm{~S}$ may play an important role in regulating $\mathrm{N}$ cycling processes. $\mathrm{H}_{2} \mathrm{~S}$ is toxic to sensitive biomolecules, including enzymes (Wang \& Chapman 1999), and is known to inhibit $\mathrm{N}$ transformations, such as nitrification (Joye \& Hollibaugh 1995) and heterotrophic denitrification (Senga et al. 2006). However, in habitats where nitrate and reduced sulfur compounds occur concomitantly, the latter can also be used as an energy source by chemolithoautotrophs, with $\mathrm{NO}_{3}{ }^{-}$as the electron acceptor, yielding $\mathrm{N}_{2}$ and thus enhancing denitrification rates. Therefore, $\mathrm{H}_{2} \mathrm{~S}$ may have a non-linear effect on rates of nitrogen cycling because it can both enhance and inhibit key $\mathrm{N}$ transformation processes.

Denitrification by S-oxidizing bacteria has been documented in marine ecosystems (Brettar \& Rheinheimer 1991, Shao et al. 2010) and has been sug- gested to occur in freshwater wetlands (Burgin \& Hamilton 2008, Payne et al. 2009). Our previous work identified Sulfurimonas denitrificans as 1 microbe potentially contributing to this process in wetland sediments (Burgin \& Hamilton 2008). To our knowledge, that study was the first reported isolation of $S$. denitrificans from freshwater habitats. The $S$. denitrificans genome contains all of the genes necessary for the complete reduction of $\mathrm{NO}_{3}^{-}$to $\mathrm{N}_{2}$ and uses the Sox pathway to oxidize reduced sulfur (S) species completely to $\mathrm{SO}_{4}{ }^{2-}$ (Sievert et al. 2008).

Here, we report an experiment that took advantage of a naturally occurring $\mathrm{H}_{2} \mathrm{~S}$ gradient (2 to $95 \mu \mathrm{M}$ over $1 \mathrm{~m}$ of depth) in a thermally stratified, eutrophic lake to examine how $\mathrm{H}_{2} \mathrm{~S}$ concentrations influence $\mathrm{N}$ transformations and microbial dynamics. In situ incubations of lake water with isotopically enriched ${ }^{15} \mathrm{NO}_{3}{ }^{-}$allowed us to follow the fate of added $\mathrm{NO}_{3}{ }^{-}$, simulating natural inputs that could occur via groundwater inflows or surface runoff. We also used quantitative PCR (qPCR) to track the response of populations of a denitrifying Sulfurimonas bacterium to the $\mathrm{NO}_{3}{ }^{-}$addition at varying $\mathrm{H}_{2} \mathrm{~S}$ concentrations. Our goals were to (1) determine the fate of $\mathrm{NO}_{3}{ }^{-}$in a eutrophic lake, including whether the reduction endproducts are affected by $\mathrm{H}_{2} \mathrm{~S}$ concentrations, and (2) test if bacteria that actively couple $\mathrm{N}$ and $\mathrm{S}$ in dissimilatory reactions respond to the $\mathrm{H}_{2} \mathrm{~S}$ gradient in ways that would explain patterns of denitrification.

\section{MATERIALS AND METHODS}

\section{Study site}

We conducted our study at Wintergreen Lake, Michigan, USA, an 18 ha eutrophic, glacial kettle lake located at the Kellogg Bird Sanctuary (maximum depth $=6.3 \mathrm{~m}$ ). The lake has been the subject of intensive study for decades (Wetzel 2001), including research on sulfur cycling (King \& Klug 1980, 1982) and phototrophic sulfur bacteria (Vila et al. 1998). A vertical thermal profile shortly before our field experiment (July 2006) showed that the lake was stratified with a thermocline at $\sim 5.25 \mathrm{~m}$ below the surface (Fig. 1A). The metalimnetic waters (from 4.5 to $5.5 \mathrm{~m}$ ) contained no detectable $\mathrm{NO}_{3}^{-}(<1 \mu \mathrm{M})$, relatively low concentrations of $\mathrm{SO}_{4}{ }^{2-}$ compared to the epilimnetic waters, and high concentrations of $\mathrm{NH}_{4}^{+}$(Fig. 1B). We also observed a strong $\mathrm{H}_{2} \mathrm{~S}$ gradient across the $1 \mathrm{~m}$ depth range $(4.5 \mathrm{~m}: 1.8 \pm 0.9 \mu \mathrm{M}, 5.0 \mathrm{~m}: 24.5 \pm$ $5.1 \mu \mathrm{M}, 5.5 \mathrm{~m}: 93.9 \pm 6.0 \mu \mathrm{M})$. Analytical methods are detailed in the following section. 

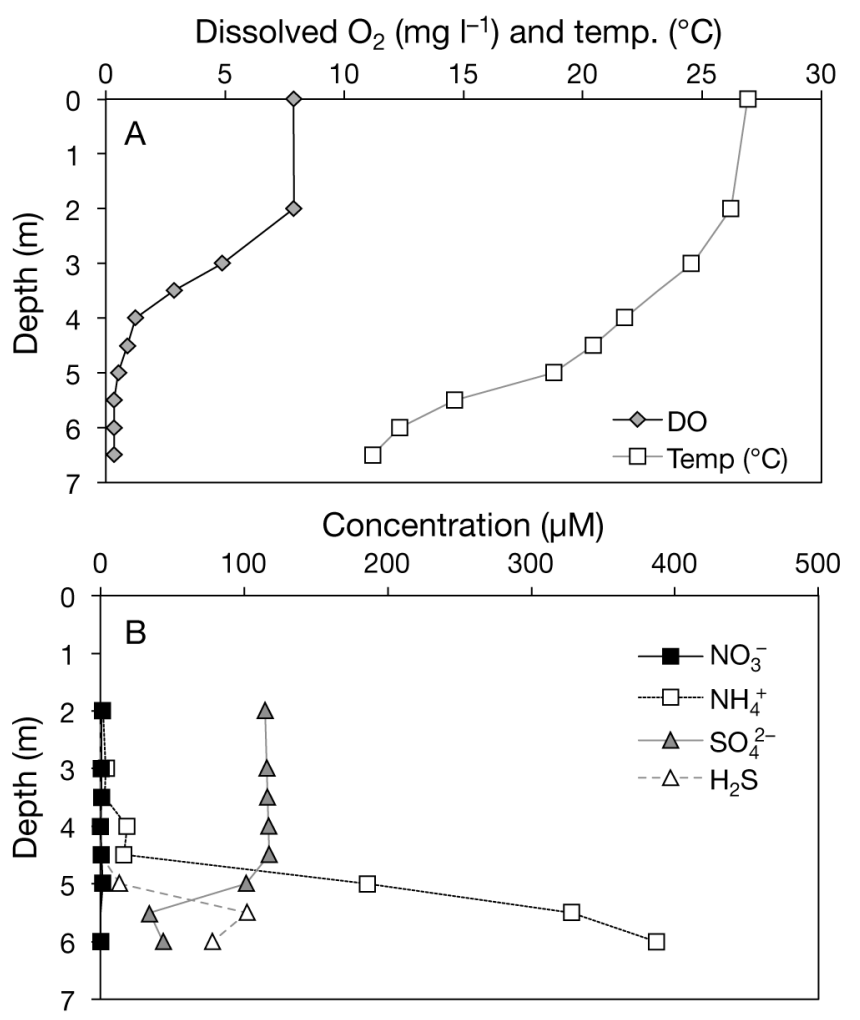

Fig. 1. Depth profiles of (A) dissolved $\mathrm{O}_{2}$ (DO) and temperature and (B) water chemistry $\left(\mathrm{NO}_{3}{ }^{-}, \mathrm{NH}_{4}{ }^{+}, \mathrm{SO}_{4}{ }^{2-}\right.$, and $\left.\mathrm{H}_{2} \mathrm{~S}\right)$ from Wintergreen Lake, Michigan, USA, at the initiation of the experiment in August 2006

The lake's natural chemical gradient allowed us to test the influence of $\mathrm{H}_{2} \mathrm{~S}$ on $\mathrm{N}$ cycling by planktonic bacterial populations under field conditions. In late summer, $\mathrm{NO}_{3}{ }^{-}$was uniformly low throughout the water column, while $\mathrm{NH}_{4}{ }^{+}$increased to nearly $400 \mu \mathrm{M}$ in the bottom waters (Fig. 1B). The $\mathrm{pH}$ ranged from 9.05 in surface waters to 6.8 near the bottom, and was 7.2 to 7.9 at the depths under study here (4.5 to $5.5 \mathrm{~m}$ ). The photosynthetic compensation point $(1 \%$ of surface irradiance) occurred at $4.2 \mathrm{~m}$. The specific conductance (corrected to $25^{\circ} \mathrm{C}$ ) of the lake water ranged from $304 \mu \mathrm{S} \mathrm{cm}{ }^{-1}$ at the surface to $683 \mu \mathrm{S}$ $\mathrm{cm}^{-1}$ near the bottom; precipitation, sedimentation, and redissolution of calcium carbonate over the period of summer stratification produces much of this vertical differentiation in conductance (Hamilton et al. 2009).

\section{Field experiment}

We designed a field experiment to examine the responses of the bacterial processes across the metalimnetic $\mathrm{H}_{2} \mathrm{~S}$ gradient to added $\mathrm{NO}_{3}{ }^{-}$. The experi- ment was set up on 21 August 2006, a time when the summer stratification of the water column was close to its maximum vertical differentiation. We used a peristaltic pump (GeoPump) to collect water from depths of 4.5, 5.0, and $5.5 \mathrm{~m}$, transferring the samples to 11 Nalgene LPE bottles by pumping water into the bottles from the bottom and allowing them to overflow to minimize the entrainment of atmospheric $\mathrm{O}_{2}$. Measurements of $\mathrm{H}_{2} \mathrm{~S}$ in both the treatment and control bottles on the following day confirmed that the sample transfer did not alter the $\mathrm{H}_{2} \mathrm{~S}$ gradient. To test the effects of $\mathrm{H}_{2} \mathrm{~S}$ concentration and the in situ $\mathrm{NO}_{3}{ }^{-}$ reduction processes, bottles were randomly assigned to 3 treatments: (1) live controls (labeled 'live') composed of ambient lake water), (2) killed controls ('killed') containing added $\mathrm{NaCl}$ at a final concentration of $300 \mathrm{~g} \mathrm{l}^{-1}$ to arrest biological activity as well as added ${ }^{15} \mathrm{NO}_{3}{ }^{-}$(final concentration of $267 \mu \mathrm{M}$ ), and (3) added ${ }^{15} \mathrm{NO}_{3}{ }^{-}\left({ }^{15} \mathrm{~N}\right.$,' final concentration of $\left.267 \mu \mathrm{M}\right)$. We used $\mathrm{NaCl}$ for the killed control because $\mathrm{H}_{2} \mathrm{~S}$ can react with many other poisons (Brock 1978). Three replicate ${ }^{15} \mathrm{~N}$-treated bottles were positioned at each of the 3 depths; these were grouped with 1 live and 1 killed control per depth for a total of 5 bottles per depth and 15 bottles total per line (a line refers to a string of bottles with an anchor and a float). Four replicate lines were positioned together so that 1 line (15 bottles) could be destructively harvested each day of the experiment (22 to 25 August 2006). The $\mathrm{NO}_{3}{ }^{-}$addition resulted in higher concentrations than those present in the lake during the study; however, this concentration was well within the range of $\mathrm{NO}_{3}{ }^{-}$ concentrations found in southern Michigan groundwaters that discharge into groundwater-fed lakes, such as Wintergreen Lake.

\section{Hydrochemical and isotopic measurements}

Upon opening the bottles, water was immediately and carefully removed for analysis of ${ }^{15} \mathrm{~N}$ gases and $\mathrm{H}_{2} \mathrm{~S}$, taking care to minimize atmospheric gas exchange. Dissolved gases were extracted using a static headspace equilibrium method (Hamilton \& Ostrom 2007), followed by transfer of the headspace gas samples to evacuated Exetainers (Labco) that were sent to the Stable Isotope Facility at the University of California at Davis for analysis of $\delta^{15} \mathrm{~N}$ in $\mathrm{N}_{2} \mathrm{O}$ and $\mathrm{N}_{2}$ (including ${ }^{15} \mathrm{~N}:{ }^{14} \mathrm{~N}\left({ }^{29} \mathrm{~N}_{2}\right)$ and ${ }^{15} \mathrm{~N}:{ }^{15} \mathrm{~N}$ $\left({ }^{30} \mathrm{~N}_{2}\right)$ forms). A subsample of the water was immediately removed and fixed (i.e. colorimetric reagents added) in the field for analysis of dissolved $\mathrm{H}_{2} \mathrm{~S}$ by the methylene blue spectrophotometric method 
(Golterman \& Clymo 1969). The gas-extracted water was then filtered through $0.45 \mu \mathrm{m}$ polyethersulfone membrane filters. Samples for ${ }^{15} \mathrm{NH}_{4}{ }^{+}$were collected by a modified diffusion method (Holmes et al. 1998), trapping the $\mathrm{NH}_{4}{ }^{+}$on filters, which were analyzed on a stable isotope ratio mass spectrometer at Michigan State University's Isotope Biogeochemistry Laboratory. Sub-samples were also taken to determine the $\mathrm{NH}_{4}{ }^{+}$concentration using the phenylhypochlorite method (Aminot et al. 1997) and for $\mathrm{NO}_{3}{ }^{-}$and $\mathrm{SO}_{4}{ }^{2-}$ on a Dionex membrane-suppression ion chromatograph.

Stable $\mathrm{N}$ isotope ratios were converted to mole fractions and multiplied by $\mathrm{N}$ pool sizes to yield masses of ${ }^{15} \mathrm{~N}$ tracer in each pool $\left(\mathrm{N}_{2}, \mathrm{~N}_{2} \mathrm{O}\right.$, and $\mathrm{NH}_{4}{ }^{+}$), thereby facilitating comparison of the flux rates. In the case of dissolved $\mathrm{N}_{2}$, we used the atmospheric equilibrium concentration at the temperature of the sampling depth.

\section{Molecular methods}

From previous work, we determined that a close relative of Sulfurimonas denitrificans was possibly responsible for coupled $\mathrm{N}-\mathrm{S}$ cycling documented in a freshwater ecosystem near Wintergreen Lake (Burgin \& Hamilton 2008). Therefore, we used primers to target bacteria related to $S$. denitrificans (Labrenz et al. 2004, Höfle et al. 2005, Brettar et al. 2006). Our goal in employing these primers was to link the measured biogeochemical processes (e.g. denitrification) with the population dynamics of bacteria known to couple sulfur oxidation with $\mathrm{NO}_{3}{ }^{-}$reduction to $\mathrm{N}_{2}$. Specifically, we used OST 1F (5'-TCA GAT GTG AAA TCC AAT GGC TCA-3') and OST 1R (5'-CTT AGC GTC AGT TAT GTT CCA GG-3'). These primers were designed to target the genus Sulfurimonas in the Baltic Sea; analysis of the PCR products showed that the amplified partial 16S rRNA gene sequences from Wintergreen Lake were closely related to $S$. autotrophica (A. Burgin unpubl. data). Of our 8 sequences, 7 were identical to each other, and the eighth had $96 \%$ similarity to the other 7 sequences. Because organisms sharing $>95 \% 16 \mathrm{~S}$ rRNA gene sequence identity are commonly considered to be of the same genus, throughout the remainder of the paper we refer to the amplified organisms as denitrifying Sulfurimonas.

The aforementioned primers were used to amplify DNA that had been extracted from filters using a MoBio UltraClean Water DNA isolation kit following the manufacturer's instructions. For PCR amplifica- tion, $50 \mu \mathrm{l}$ reactions were carried out with HotStart Buffer and Taq polymerase at the recommended final concentrations (Promega). A gradient PCR was used to optimize PCR thermal conditions, and an optimal annealing temperature was found to be between 57 and $59^{\circ} \mathrm{C}$. The reaction ran an initial denaturing step at $95^{\circ} \mathrm{C}$ for $15 \mathrm{~min}$, followed by 40 cycles of $94^{\circ} \mathrm{C}$ for $30 \mathrm{~s}$, and the optimized annealing temperatures of $58^{\circ} \mathrm{C}$ for $40 \mathrm{~s}$ and $72^{\circ} \mathrm{C}$ for $2 \mathrm{~min}$. The OST-amplified DNA was gel-purified using a Novagen SpinPrep Gel DNA kit following the manufacturer's instructions. The target DNA was then cloned into Escherichia coli using an Invitrogen TOPO-TA kit per the manufacturer's instructions. Eight colonies were selected and PCR-amplified using M13 primers and manufacturer-suggested PCR conditions. M13 PCR product was purified with a QIAquick PCR purification kit (Qiagen). Sequencing confirmed the taxonomic identity of our PCR amplicons as members of the genus Sulfurimonas. Sequencing was conducted at the Research Technology Support Facility at Michigan State University. All sequences obtained in the present study were deposited in GenBank (accession numbers GU937440 to GU937447). The sequences, along with reference sequences obtained from GenBank, were aligned and trimmed using ClustalX. The $150 \mathrm{bp}$ alignment was then used as the basis for a phylogenetic tree constructed using MrBayes, run on the CIPRES Web Portal (www.phylo.org).

Quantification of denitrifying Sulfurimonas populations was performed using BioRad iQ SYBR Green Mastermix and an Eppendorf Mastercycler ep realplex $^{2}$ qPCR thermocycler. The qPCR mixtures $(15 \mu \mathrm{l})$ contained master mix, $900 \mathrm{nM}$ OST $1 \mathrm{~F}$, and $300 \mathrm{nM}$ OST 1R. The assay included an initial denaturing step at $95^{\circ} \mathrm{C}$ for $15 \mathrm{~min}$, followed by 40 cycles of $94^{\circ} \mathrm{C}$ for $30 \mathrm{~s}, 58^{\circ} \mathrm{C}$ for $40 \mathrm{~s}$, and $72^{\circ} \mathrm{C}$ for $50 \mathrm{~s}$. Our cloned and purified PCR product was also used as a standard for our qPCR assay after being quantified with a Nanodrop spectrophotometer. We also used qPCR primers that targeted the bacterial 16S rRNA gene as a way to estimate the relative contribution of denitrifying Sulfurimonas populations to the total bacterial community in the bottle incubations. The bacterial 16S rRNA qPCR reactions $(15 \mu \mathrm{l})$ contained master mix and $667 \mathrm{nM}$ each of the 340f/533r primers. The total bacterial assay included an initial denaturing step at $95^{\circ} \mathrm{C}$ for $15 \mathrm{~min}$, followed by 40 cycles of $94^{\circ} \mathrm{C}$ for $30 \mathrm{~s}, 68^{\circ} \mathrm{C}$ for $40 \mathrm{~s}, 72^{\circ} \mathrm{C}$ for $50 \mathrm{~s}$, and data collection at $83.5^{\circ} \mathrm{C}$ (Jones \& Lennon 2009). The qPCR amplification efficiencies were always between 0.9 and 1.1, and there was no evidence for primer dimers based on the melting curves. 


\section{Statistical analysis}

We used 1-way analysis of variance (ANOVA) to compare rates of denitrification and DNRA across depths (SYSTAT 11 software). To compare changes in the abundance of denitrifying Sulfurimonas populations over time and depth, we conducted repeated measures (RM) ANOVA (SAS PROC MIXED) with covariance structure selected using the Bayesian Information Criterion (Wolfinger \& Chang 1999).

\section{RESULTS}

Microorganisms processed the added $\mathrm{NO}_{3}{ }^{-}$differently at the 3 depths in Wintergreen Lake. At the most oxic and shallow depth $(4.5 \mathrm{~m})$, nearly all of the added $\mathrm{NO}_{3}{ }^{-}(\sim 267 \mu \mathrm{M})$ was removed by Day 3 (Fig. 2). During this time, we observed a large increase in $\mathrm{NH}_{4}{ }^{+}$, but isotopic evidence indicates that this was not a product of DNRA. The water at $4.5 \mathrm{~m}$ depth had very low concentrations of $\mathrm{H}_{2} \mathrm{~S}(2.2 \pm$ $0.2 \mu \mathrm{M}$ ), which changed little over the course of the experiment. The $\mathrm{SO}_{4}{ }^{2-}$ concentrations decreased slightly from 120 to $108 \mu \mathrm{M}$. At the intermediate depth $(5.0 \mathrm{~m})$, more than half $(185 \mu \mathrm{M})$ of the added $\mathrm{NO}_{3}{ }^{-}$remained on the last day (Fig. 2). The $25 \mu \mathrm{M}$ $\mathrm{H}_{2} \mathrm{~S}$ present in the beginning was quickly removed (to below our detection limit of $1.0 \mu \mathrm{M}$ ) and remained low. This drop in $\mathrm{H}_{2} \mathrm{~S}$ was accompanied by an increase of $\sim 10 \mu \mathrm{M}$ in $\mathrm{SO}_{4}{ }^{2-}$. At the most $\mathrm{H}_{2} \mathrm{~S}$-rich $(95 \mu \mathrm{M})$ and deepest depth $(5.5 \mathrm{~m})$, the $\mathrm{NO}_{3}{ }^{-}$was completely removed, with a concomitant increase of $85 \mu \mathrm{M}$ in $\mathrm{SO}_{4}{ }^{2-}$ (Fig. 2). At $5.5 \mathrm{~m}$, the microbial populations converted $\mathrm{H}_{2} \mathrm{~S}$ to $\mathrm{SO}_{4}{ }^{2-}$ in a nearly $1: 1$ stoichiometric ratio; discrepancy from this expected 1:1 ratio at $5.0 \mathrm{~m}$ could be accounted for via intracellular storage (as elemental $\mathrm{S}$ ) or incomplete conversion via unmeasured intermediates (elemental $\mathrm{S}$ or thiosulfate).

The $\mathrm{NO}_{3}{ }^{-}$added to the bottles was reduced mainly to $\mathrm{N}_{2}$ via denitrification (Fig. 3A) and to a lesser extent to $\mathrm{NH}_{4}{ }^{+}$via DNRA (Fig. 3B). Rates of $\mathrm{NO}_{3}{ }^{-}$ reduction, denitrification, and DNRA were calculated over Days 0 to 3 of the experiment because all of the reactants and products of the focal processes were measurable during this time period, and changes in concentrations, where they occurred, were approximately linear. Denitrification rates increased significantly with depth (and with increasing $\mathrm{H}_{2} \mathrm{~S}$ concentrations), ranging from $1 \mu \mathrm{M}{ }^{15} \mathrm{~N} \mathrm{~d}^{-1}$ at $4.5 \mathrm{~m}$ to $17 \mu \mathrm{M}^{15} \mathrm{~N} \mathrm{~d}^{-1}$ at $5.5 \mathrm{~m}$ (Fig. $3 \mathrm{~A}_{i} F_{2,6}=252.5$, $\mathrm{p}<0.001$ ). A larger fraction of overall $\mathrm{NO}_{3}{ }^{-}$reduction
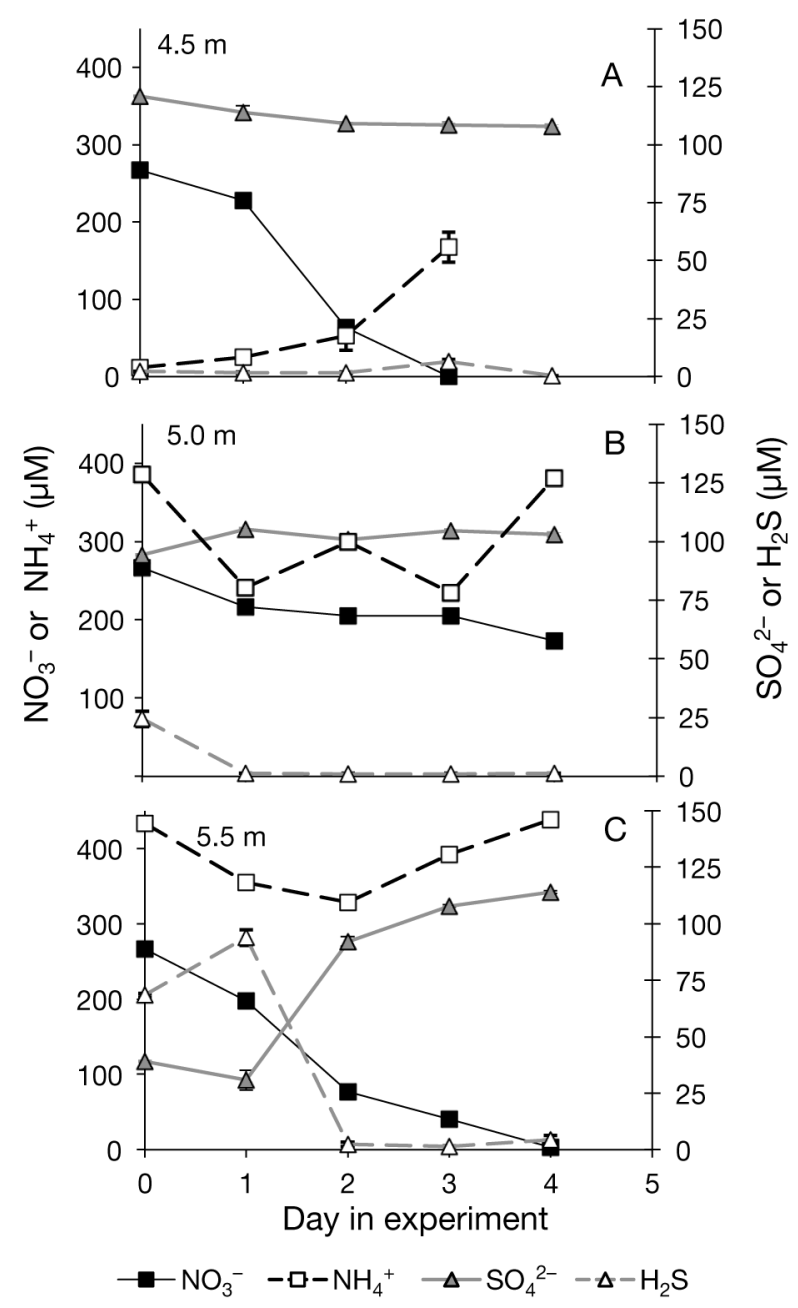

Fig. 2. Changes in dissolved $\mathrm{N}$ and $\mathrm{S}$ species over time at (A) $4.5 \mathrm{~m}$, (B) $5.0 \mathrm{~m}$, and (C) $5.5 \mathrm{~m}$ after addition of $\mathrm{NO}_{3}{ }^{-}$ in the field experiment (means of the 3 treatment bottles \pm 1 standard error of the mean). The controls (data not shown) showed little change compared to the $\mathrm{NO}_{3}{ }^{-}$addition treatment

(Fig. 3C) could be attributed to denitrification at the 5.0 and $5.5 \mathrm{~m}$ depths, whereas a much smaller fraction $(\sim 1 \%)$ was denitrified at $4.5 \mathrm{~m}$. DNRA accounted for 1 to $15 \%$ of the $\mathrm{NO}_{3}{ }^{-}$reduction (Fig. 3B,C). DNRA rates were not affected by increasing depth or $\mathrm{H}_{2} \mathrm{~S}$ concentration, though there were significant differences in rates among depths (Fig. 3B) $\left(F_{2,6}=10.4, p=\right.$ 0.01). Anammox was not a significant source of the tracer ${ }^{15} \mathrm{~N}$ in $\mathrm{N}_{2}$ because 96 to $100 \%$ of the tracer ${ }^{15} \mathrm{~N}$ appeared in the ${ }^{15} \mathrm{~N}:{ }^{15} \mathrm{~N}$ form, whereas anammox would have produced ${ }^{15} \mathrm{~N}:{ }^{14} \mathrm{~N}$ through the partial denitrification of the added ${ }^{15} \mathrm{NO}_{3}{ }^{-}$to ${ }^{15} \mathrm{NO}_{2}{ }^{-}$followed by its reaction with ${ }^{14} \mathrm{NH}_{4}{ }^{+}$(data not shown). Dissolved $\mathrm{N}_{2} \mathrm{O}$ accounted for a very minor proportion of the overall $\mathrm{NO}_{3}{ }^{-}$reduction $(<0.1 \%)$ and did not 

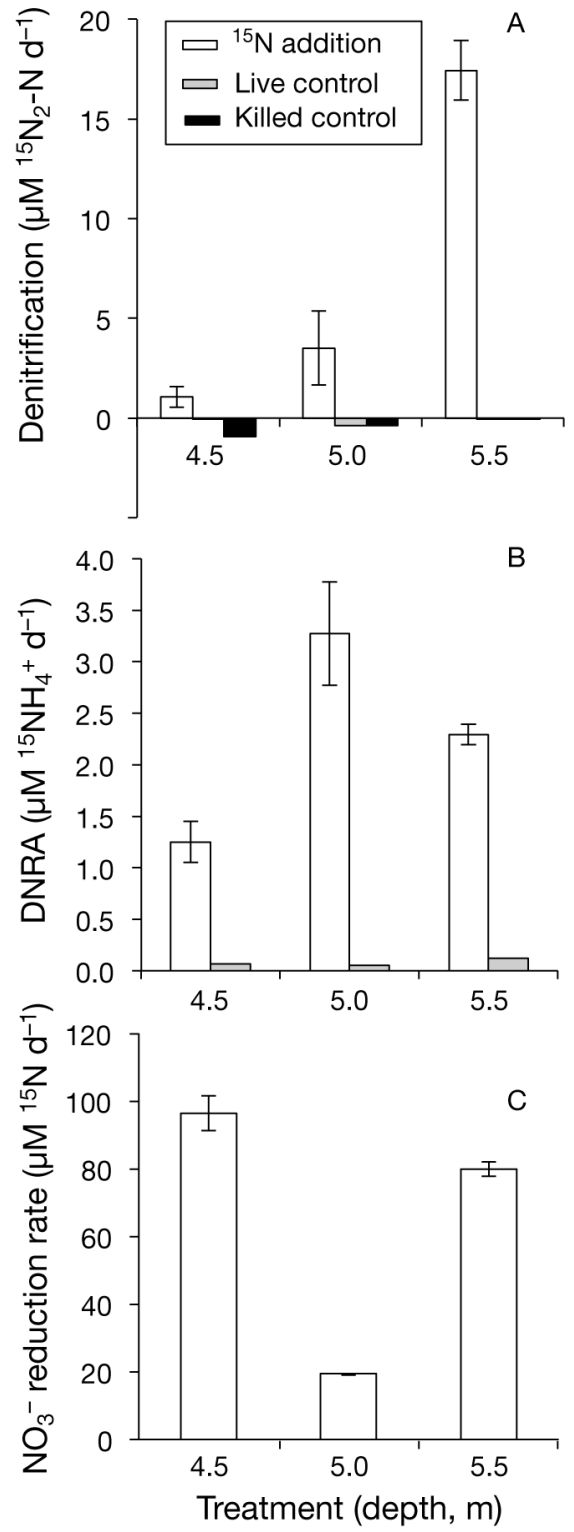

Fig. 3. (A) Denitrification, (B) dissimilatory nitrate reduction to ammonium (DNRA), and (C) nitrate reduction rates in treatment and control bottles from the field experiment (means over the incubation from 3 treatment bottles per depth \pm 1 standard error of the mean). The live and killed controls had only 1 bottle per treatment, and thus, no standard error is presented. Only live controls are plotted for comparison with DNRA rates, and neither the live nor killed controls are plotted on the $\mathrm{NO}_{3}$ reduction rates due to detection limits. Note the changes in scale among panels

show any clear patterns over time or among depths (data not shown).

The molecular data corroborate the isotope data and suggest that denitrification was coupled to the activity of S-oxidizing bacteria. The abundance of denitrifying Sulfurimonas bacteria changed through time as a function of depth (RM-ANOVA, Time $x$ Depth, $F_{6,10}=10.1, \mathrm{p}=0.001$; Fig. 4 ). The denitrifying Sulfurimonas was present at low levels in the live controls, ranging from 8 to 22 cells $^{-1}$. In contrast, the highest abundance measured in the $5.5 \mathrm{~m}$ depth ${ }^{15} \mathrm{~N}$ treated bottles was nearly 60000 cells l$^{-1}$, indicating a rapid increase of the population. When expressed as a fraction of the 16S rRNA gene copy number (Fig. 4), the relative abundance of denitrifying Sulfurimonas increased from 3 to $65 \%$ in the $5.5 \mathrm{~m}$ treatment, whereas the relative abundance of denitrifying Sulfurimonas in the 4.5 and $5.0 \mathrm{~m}$ treatments was generally much lower (3 to $5 \%$ ), particularly after the first day.

\section{DISCUSSION}

The addition of nitrate to anoxic, sulfidic lake water stimulated rapid, microbially mediated biogeochemical reactions in which sulfur oxidation was linked to nitrate reduction to $\mathrm{N}_{2}$. This conclusion is supported by stoichiometric comparisons of $\mathrm{NO}_{3}{ }^{-}$and $\mathrm{H}_{2} \mathrm{~S}$ concentration changes, stable isotope tracing, and molecular evidence for an increase in populations of sulfur-oxidizing bacteria capable of denitrification. We elaborate on these lines of evidence below.

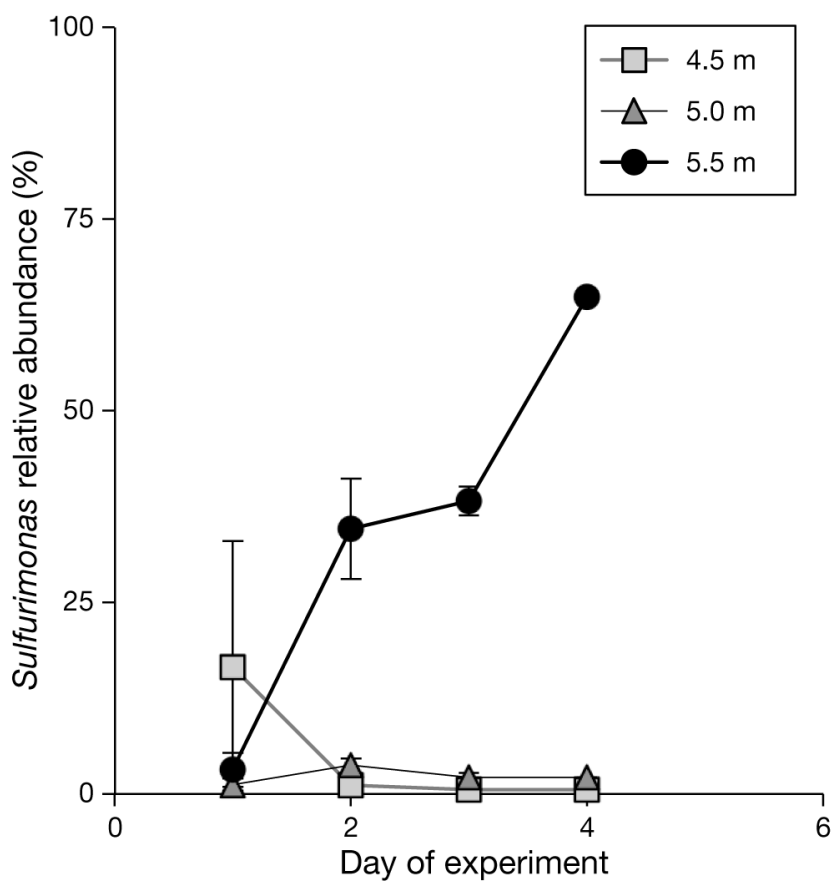

Fig. 4. Sulfurimonas. Population dynamics in the $\mathrm{NO}_{3}{ }^{-}$ amended treatment bottles over time and depth based on qPCR (means from the 3 treatment bottles per depth and day \pm 1 standard error of the mean). The relative abundance of denitrifying Sulfurimonas is expressed as a fraction of the 16S rRNA gene copy number 


\section{Evidence for sulfur-driven denitrification in freshwater ecosystems}

Stoichiometric calculations provide an estimate of the fraction of $\mathrm{NO}_{3}{ }^{-}$removal due to $\mathrm{S}$ oxidation as indicated by $\mathrm{SO}_{4}{ }^{2-}$ production. In the $\mathrm{S}$ oxidation reaction, wherein $\mathrm{NO}_{3}{ }^{-}$is reduced to $\mathrm{N}_{2}, 8$ moles of $\mathrm{NO}_{3}{ }^{-}$are removed for every 5 moles of $\mathrm{SO}_{4}{ }^{2-}$ produced (Fossing et al. 1995, Burgin \& Hamilton 2008):

$5 \mathrm{HS}^{-}+8 \mathrm{NO}_{3}^{-}+3 \mathrm{H}^{+} \rightarrow 5 \mathrm{SO}_{4}^{2-}+4 \mathrm{~N}_{2}+4 \mathrm{H}_{2} \mathrm{O}$

Given this stoichiometry and the amount of $\mathrm{SO}_{4}{ }^{2-}$ produced, we estimated that $\mathrm{SO}_{4}{ }^{2-}$ production did not account for $\mathrm{NO}_{3}{ }^{-}$removal at $4.5 \mathrm{~m}$ but accounted for $6 \%$ of the total $\mathrm{NO}_{3}{ }^{-}$removal at $5.0 \mathrm{~m}$ and $51 \%$ of the total $\mathrm{NO}_{3}{ }^{-}$removal at $5.5 \mathrm{~m}$ (Fig. 2). We combined the fraction of $\mathrm{NO}_{3}{ }^{-}$removal to denitrification (Fig. 3A) with the fraction of $\mathrm{NO}_{3}{ }^{-}$removal attributable to $\mathrm{SO}_{4}{ }^{2-}$ production to estimate the fraction of denitrification linked to $\mathrm{SO}_{4}{ }^{2-}$ production. Therefore, at $5.5 \mathrm{~m}$, the majority of the denitrification could be coupled to chemolithoautotrophic S oxidation rather than anaerobic respiration of organic matter. These contributions were much lower at the 5 and $4.5 \mathrm{~m}$ depths because rates of denitrification (Fig. 3A) and $\mathrm{SO}_{4}{ }^{2-}$ production (Fig. 2) were substantially lower or undetectable. However, estimates based on $\mathrm{SO}_{4}{ }^{2-}$ production alone are conservative because partial oxidation of $\mathrm{H}_{2} \mathrm{~S}$ to elemental $\mathrm{S}$ or significant intracellular accumulation of either $\mathrm{NO}_{3}{ }^{-}$or elemental $\mathrm{S}$ could account for additional coupling not measured by our methods (e.g. Kamp et al. 2006).

Coupled $\mathrm{N}-\mathrm{S}$ cycling has been known for more than a decade to occur in certain marine ecosystems (Brettar \& Rheinheimer 1991, Fossing et al. 1995) and has been incorporated into bioreactor engineering (Cardoso et al. 2006), and our study suggests that reduced $\mathrm{S}$ can be a major driver of denitrification in natural freshwater ecosystems. Evidence for sulfurdriven denitrification has been reported in marine ecosystems, including oceanic redoxclines (Brettar et al. 2006, Grote et al. 2008), near-coastal upwelling zones (Fossing et al. 1995, Schulz et al. 1999), and engineered mariculture systems (Cytryn et al. 2005a, Sher et al. 2008). The patterns of biogeochemical activity that we observed over depth are very similar to those documented in the Baltic Sea (Brettar \& Rheinheimer 1991, Brettar et al. 2006), albeit over a much smaller spatial scale (1 m vs. 10s of meters). Concentrations of $\mathrm{H}_{2} \mathrm{~S}$ in Wintergreen Lake were comparable to those measured in the Baltic Sea, ranging from 0 to $100 \mu \mathrm{M}$ in the water column, whereas the highest reported $\mathrm{H}_{2} \mathrm{~S}$ concentration in the Gotland Deep area of the Baltic was $\sim 150 \mu \mathrm{M}$ (Brettar \& Rheinheimer 1991). In laboratory experiments, $\mathrm{H}_{2} \mathrm{~S}$ additions increased denitrification (Brettar \& Rheinheimer 1991) by as much as we saw across the ambient $\mathrm{H}_{2} \mathrm{~S}$ gradient in Wintergreen Lake (Fig. 3A). The occurrence, importance, and distribution of these $\mathrm{N}-\mathrm{S}$ coupling processes in freshwater ecosystems, however, remain almost completely unexplored.

Few studies have examined the effects of $\mathrm{H}_{2} \mathrm{~S}$ concentrations on the multiple processes that contribute to $\mathrm{NO}_{3}{ }^{-}$removal, including denitrification, DNRA, and anammox. Our results suggest that in the hypolimnetic lake water where $\mathrm{H}_{2} \mathrm{~S}$ was available, denitrification was the most important measured removal process; however, despite the use of ${ }^{15} \mathrm{~N}$ tracers, we were not able to account for the full mass of added nitrate. This is likely because we were not able to measure assimilation, a potentially important process. There was, however, substantial variation in the fate of $\mathrm{NO}_{3}{ }^{-}$over the $1 \mathrm{~m}$ depth range we investigated. Furthermore, $\mathrm{NO}_{3}{ }^{-}$removal rates varied over the depth range, with the majority of $\mathrm{NO}_{3}{ }^{-}$removed quickly at 4.5 and $5.5 \mathrm{~m}$, but much less $\mathrm{NO}_{3}{ }^{-}$removal at $5.0 \mathrm{~m}$ (Figs. $2 \& 3 \mathrm{C}$ ). These differences in biogeochemical processes (Figs. 2 \& 3) and microbial population dynamics (Fig. 4) highlight the high degree of spatial variation that can develop over relatively small distances $(1 \mathrm{~m})$ in a seasonally stratified water column.

\section{Bacterial population response to $\mathrm{NO}_{3}{ }^{-}$addition}

The bacteria implicated in linking the $\mathrm{N}$ and $\mathrm{S}$ cycles in Wintergreen Lake appear to be closely related to bacteria that have been shown to perform similar functions in the Baltic Sea (Brettar et al. 2006). All 8 of our sequences shared $>95 \%$ sequence identity with a sequence obtained from similar incubation experiments conducted in the Baltic Sea (AJ810529) (Brettar et al. 2006, A. Burgin unpubl. data) and were identical to other environmental sequences recovered from freshwater, anoxic, and sulfidic environments (Briée et al. 2007, Amaral-Zettler et al. 2008, Porter et al. 2009) (Fig. 5). Our results are consistent with the interpretation that the primers we used target populations of denitrifying Sulfurimonas bacteria that couple the $\mathrm{N}$ and $\mathrm{S}$ cycles by reducing $\mathrm{NO}_{3}{ }^{-}$to oxidize $\mathrm{H}_{2} \mathrm{~S}$, creating $\mathrm{N}_{2}$ and $\mathrm{SO}_{4}{ }^{2-}$ (Figs. 2 \& 3). The ambient populations of the bacteria, as inferred from the gene copies on Day 1 of the experiment (Fig. 4), showed higher abundance with increased $\mathrm{H}_{2} \mathrm{~S}$. The 


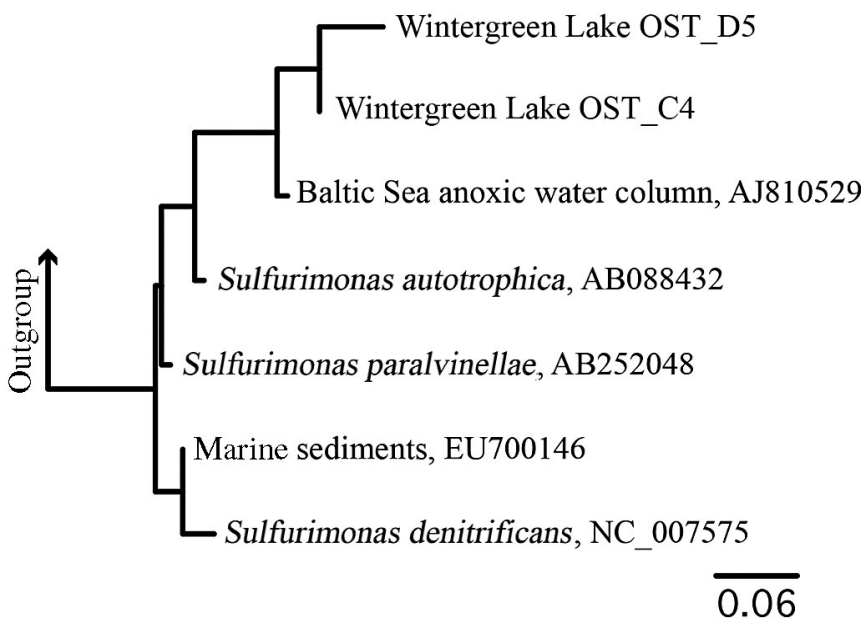

Fig. 5. Phylogenetic tree of a portion of the denitrifying Sulfurimonas 16S rRNA gene, including sequences isolated from Wintergreen Lake (OST_C4 and D5). Sequences obtained from our experiment fall within the Sulfurimonas genus and are closely related to a sequence obtained during similar work in the Baltic Sea. GenBank accession numbers are given where available. The scale bar indicates $6 \%$ sequence divergence

populations targeted by the Brettar et al. (2006) primers clearly responded to the $\mathrm{NO}_{3}{ }^{-}$addition, with the most growth in the presence of the highest $\mathrm{H}_{2} \mathrm{~S}$ and $\mathrm{NO}_{3}{ }^{-}$, as in the bottles incubated at $5.5 \mathrm{~m}$ depth (Fig. 4).

Based on whole-genome sequencing of Sulfurimonas denitrificans, we know that this bacterium has the genetic capacity to link the $\mathrm{N}$ and $\mathrm{S}$ cycles through chemolithoautotrophic denitrification (Sievert et al. 2008). We do not know, however, if other microorganisms in the Wintergreen Lake samples also carried out this metabolism. For example, the coupling of $\mathrm{N}-\mathrm{S}$ cycling is performed by other bacteria besides $S$. denitrificans, including Thiothrix (Nielsen et al. 2000, Cytryn et al. 2005b), Thioploca (Fossing et al. 1995, Jorgensen \& Gallardo 1999), Beggiatoa (Kamp et al. 2006), and Thiomargarita (Schulz et al. 1999). Many of these are either Gammaproteobacteria or Epsilonproteobacteria, and most have been isolated from marine ecosystems. However, one study suggested that Beggiatoa species (also Gammaproteobacteria) from freshwater ecosystems can perform a similar reaction (Kamp et al. 2006). While we found evidence for the importance of denitrifying Sulfurimonas in Wintergreen Lake, the diversity of taxa with the potential for this metabolism suggests there may be other microorganisms that can couple the $\mathrm{N}$ and $\mathrm{S}$ cycles in other freshwaters. Given that the denitrifying Sulfurimo- nas was the numerically dominant member of the bacterial community (Fig. 4) at depths where a high degree of coupled N-S cycling occurred (Fig. 2), our study has identified one important group of organisms responsible for the coupling of $\mathrm{N}-\mathrm{S}$ in eutrophic freshwaters. Future research, however, should focus on identifying other freshwater microorganisms that may further contribute to coupled $\mathrm{N}-\mathrm{S}$ cycling.

\section{Freshwater sulfide as a control of denitrification}

We argue that the role of $\mathrm{NO}_{3}{ }^{-}$reduction coupled to $\mathrm{S}$ oxidation should be considered in building a mechanistic understanding of how $\mathrm{S}$ cycling affects $\mathrm{N}$ availability in freshwater aquatic ecosystems. Our finding of S-driven denitrification in a freshwater lake represents a departure from our current understanding of freshwater biogeochemistry. The general belief, particularly from an ecosystem perspective, is that all freshwater denitrification is organic carbondriven (Burgin \& Hamilton 2007). Our study provides strong evidence that $\mathrm{H}_{2} \mathrm{~S}$ controls denitrification in a type of ecosystem where it has heretofore not been regarded as important to the overall nitrogen cycle.

Sulfate concentrations in lakes can range from $<10 \mu \mathrm{M}$ to $>800 \mu \mathrm{M}$ in the region where our study was conducted (S. Hamilton unpubl. data), while $\mathrm{H}_{2} \mathrm{~S}$ concentrations in near-surface sediment porewaters can range from 0 to $>200 \mu \mathrm{M}$ (Whitmire 2003). A number of studies in the 1970s and 1980s elucidated the mechanisms and controls of $\mathrm{SO}_{4}{ }^{2-}$ reduction; however, we know relatively little about the oxidative side of $\mathrm{S}$ cycling and its role in freshwater ecosystems (Holmer \& Storkholm 2001). Tightly coupled $\mathrm{N}-\mathrm{S}$ cycling may occur in many hypolimnetic zones of lakes or otherwise seasonally or ephemerally anoxic waters, which often originate as groundwater, precipitation, or runoff that is relatively high in both $\mathrm{NO}_{3}{ }^{-}$and $\mathrm{SO}_{4}{ }^{2-}$. As illustrated in Fig. 6, potential zones of coupled N-S cycling (denoted by the whitedashed boxes) may first develop at the sedimentwater interface of a lake during spring overturn but eventually shift up into the water column as stratification sets in and an anoxic hypolimnion develops. Furthermore, $\mathrm{NO}_{3}{ }^{-}$reduction coupled to $\mathrm{S}$ oxidation may be particularly important in areas with high groundwater $\mathrm{NO}_{3}{ }^{-}$and $\mathrm{SO}_{4}{ }^{2-}$ concentrations and abundant groundwater-fed ecosystems (e.g. the glacial terrain in which Wintergreen Lake is situated). The potential importance of coupled N-S cycling in freshwaters may not have been recognized in many studies of denitrification because assays are typically 

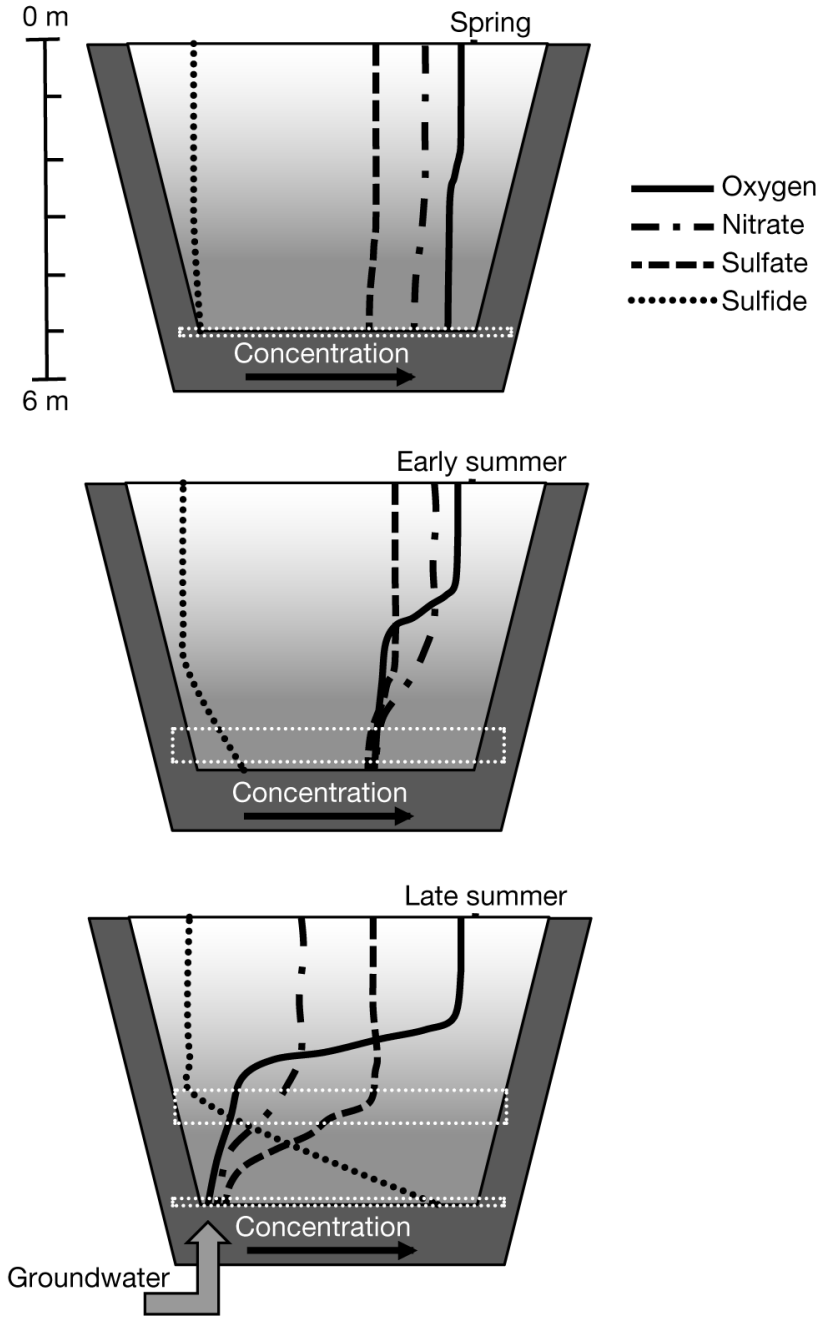

Fig. 6. Conceptual diagram of how zones of coupled N-S cycling (white dashed boxes) develop near the bottom and shift upward in a stratified lake over the spring and summer. Inflow of oxic groundwater containing $\mathrm{NO}_{3}{ }^{-}$into the anoxic hypolimnion would also provide the necessary juxtaposition of $\mathrm{NO}_{3}{ }^{-}$and $\mathrm{H}_{2} \mathrm{~S}$

performed in lab slurries that alter conditions, including sparging, which greatly reduces the availability of $\mathrm{H}_{2} \mathrm{~S}$.

Our results suggest that the controls of $\mathrm{NO}_{3}{ }^{-}$ removal are spatially variable. $\mathrm{H}_{2} \mathrm{~S}$ becomes more important as an electron donor with increasing concentration (i.e. with depth in the present study), whereas labile organic $\mathrm{C}$ is presumably a more important control at shallower depths (Fig. 3). The corollary to this result is that there may also be temporal variability in how labile $\mathrm{C}$ and reduced $\mathrm{S}$ competitively control $\mathrm{NO}_{3}{ }^{-}$removal and denitrification. We hypothesize that labile $\mathrm{C}$ availability may control denitrification more during spring and fall when the lake is completely mixed, whereas $\mathrm{S}$ may become an increasingly important control through the development of summer stratification (Fig. 6). Both labile C and $\mathrm{H}_{2} \mathrm{~S}$ are important electron donors for denitrification in the Baltic Sea (Brettar \& Rheinheimer 1991). However, in freshwaters, $\mathrm{C}$ and available $\mathrm{NO}_{3}{ }^{-}$are considered to be proximal controls of denitrification in groundwaters (Rivett et al. 2008), streams (Arango et al. 2007), and wetlands (Hill \& Cardaci 2004). Paradoxically, some studies have also demonstrated a counterintuitive lack of stimulation of denitrification with the addition of labile C (Merrill \& Zak 1992, Davidsson \& Stahl 2000). Therefore, it seems plausible that some of these conflicting results could be explained by variable and interacting influences of $\mathrm{C}$ and $\mathrm{S}$ on denitrification.

Results from our in situ experiment in eutrophic Wintergreen Lake demonstrate how distinct microbial populations (Fig. 4) are coupled to biogeochemical functioning across a naturally existing $\mathrm{H}_{2} \mathrm{~S}$ gradient (Figs. 2 \& 3). We confirmed that $\mathrm{S}$ oxidation can be an important driver of denitrification, contributing over half of the $\mathrm{NO}_{3}{ }^{-}$removal at the higher $\mathrm{H}_{2} \mathrm{~S}$ concentrations. Denitrification rates increased with increasing $\mathrm{H}_{2} \mathrm{~S}$ concentrations (Fig. 3), and this was accompanied by increased abundance of denitrifying Sulfurimonas (Fig. 4). Therefore, the role of $\mathrm{NO}_{3}{ }^{-}$ reduction coupled to $\mathrm{S}$ oxidation should be considered in building a mechanistic understanding of how $\mathrm{S}$ cycling affects $\mathrm{N}$ availability in freshwater aquatic ecosystems. Future work should focus on the spatial and temporal variation in organic carbon vs. sulfide as controls of denitrification in freshwater aquatic ecosystems.

Acknowledgements. We thank P. Groffman, M. Klug, T. Loecke, J. O'Brien, E. Payne, G.P. Robertson, M. Roth, T. Schmidt, D. Weed, B. Lehmkuhl, and S. Whitmire for their help and advice. We also thank N. Ostrom of Michigan State University's Isotope Biogeochemistry lab and D. Harris at UC Davis Stable Isotope Facility for analysis of the isotope samples. This work was supported by US National Science Foundation grants DEB-0508704, 0423627, 0516076, 0743402, and 0842441 (to S.K.H., J.T.L., and S.E.J.) and the Center for Water Sciences at Michigan State University (J.T.L. and S.K.H.). This is contribution \#1545 of the WK Kellogg Biological Station.

\section{LITERATURE CITED}

Alexander RB, Smith RA, Schwarz GE (2000) Effect of stream channel size on the delivery of nitrogen to the Gulf of Mexico. Nature 403:758-761

Amaral-Zettler LA, Rocca JD, Lamontagne MG, Dennett MR, Gast RJ (2008) Changes in microbial community structure in the wake of Hurricanes Katrina and Rita. Environ Sci Technol 42:9072-9078 
Aminot A, Kirkwood DS, Kerouel R (1997) Determination of ammonia in seawater by the indophenol-blue method: evaluation of the ICES NUTS I/C 5 questionnaire. Mar Chem 56:59-75

- Arango C, Tank J, Schaller JL, Royer TV, Bernot MJ, David MB (2007) Benthic organic carbon influences denitrification in streams with high nitrate concentration. Freshw Biol 52:1210-1222

Brettar I, Rheinheimer G (1991) Denitrification in the Central Baltic: evidence for $\mathrm{H}_{2} \mathrm{~S}$-oxidation as motor of denitrification at the oxic-anoxic interface. Mar Ecol Prog Ser 77:157-169

- Brettar I, Labrenz M, Flavier S, Bötel J, Kuosa H, Christen R, Höfle MG (2006) Identification of a Thiomicrospira denitrificans-like epsilonproteobacterium as a catalyst for autotrophic denitrification in the central Baltic Sea. Appl Environ Microbiol 72:1364-1372

- Briée C, Moreira D, Lopez-Garcia P (2007) Archaeal and bacterial community composition of sediment and plankton from a suboxic freshwater pond. Res Microbiol 158: 213-227

Brock TD (1978) The poisoned control in biogeochemical investigations. In: Krumbein WE (ed) Environmental biogeochemistry and geomicrobiology. Ann Arbor Science Publishers, Ann Arbor, MI, p 717-725

> Brunet RC, Garcia-Gil LJ (1996) Sulfide-induced dissimilatory nitrate reduction to ammonia in anaerobic freshwater sediments. FEMS Microbiol Ecol 21:131-138

Burgin AJ, Hamilton SK (2007) Have we overemphasized the role of denitrification in aquatic ecosystems? A review of nitrate removal pathways. Front Ecol Environ 5:89-96

> Burgin AJ, Hamilton SK (2008) $\mathrm{NO}_{3}{ }^{-}$driven $\mathrm{SO}_{4}{ }^{2-}$ production in freshwater ecosystems: implications for $\mathrm{N}$ and $\mathrm{S}$ cycling. Ecosystems 11:908-922

- Cardoso RB, Sierra-Alvarez R, Rowlette P, Flores ER, Gomez J, Field JA (2006) Sulfide oxidation under chemolithoautotrophic denitrifying conditions. Biotechnol Bioeng 95: 1148-1157

Cornwell JC, Kemp WM, Kana TM (1999) Denitrification in coastal ecosystems: methods, environmental controls, and ecosystem level controls. Aquat Ecol 33:41-54

> Cytryn E, van Rijn J, Schramm A, Gieseke A, de Beer D, Minz D (2005a) Identification of bacteria potentially responsible for oxic and anoxic sulfide oxidation in biofilters of a recirculating mariculture system. Appl Environ Microbiol 71:6134-6141

> Cytryn E, Minz D, Gelfand I, Neori A, Gieseke A, De Beer D, Van Rijn J (2005b) Sulfide-oxidizing activity and bacterial community structure in a fluidized bed reactor from a zero-discharge mariculture system. Environ Sci Technol 39:1802-1810

> Dalsgaard T, Thamdrup B, Canfield DE (2005) Anaerobic ammonium oxidation (anammox) in the marine environment. Res Microbiol 156:457-464

> Davidsson TE, Stahl M (2000) The influence of organic carbon on nitrogen transformations in five wetland soils. Soil Sci Soc Am J 64:1129-1136

Fossing H, Gallardo VA, Jorgensen BB, Huttel M and others (1995) Concentration and transport of nitrate by the matforming sulfur bacterium Thioploca. Nature 374:713-715

Gardner WS, McCarthy MJ (2009) Nitrogen dynamics at the sediment-water interface in shallow, sub-tropical Florida Bay: why denitrification efficiency may decrease with increased eutrophication. Biogeochemistry 95:185-198
Gardner WS, McCarthy MJ, An SM, Sobolev D, Sell KS, Brock D (2006) Nitrogen fixation and dissimilatory nitrate reduction to ammonium (DNRA) support nitrogen dynamics in Texas estuaries. Limnol Oceanogr 51: 558-568

Golterman HL, Clymo RS (1969) Methods for chemical analysis of fresh waters. Blackwell, Oxford

- Grote J, Jost G, Labrenz M, Herndl GJ, Juergens K (2008) Epsilonproteobacteria represent the major portion of chemoautotrophic bacteria in sulfidic waters of pelagic redoxclines of the Baltic and Black Seas. Appl Environ Microbiol 74:7546-7551

Hamilton SK, Ostrom NE (2007) Measurement of the stable isotope ratio of dissolved $\mathrm{N}_{2}$ in ${ }^{15} \mathrm{~N}$ tracer experiments. Limnol Oceanogr Methods 5:233-240

Hamilton SK, Bruesewitz DA, Horst GP, Sarnelle O (2009) Biogenic calcite-phosphorus precipitation as a negative feedback to lake eutrophication. Can J Fish Aquat Sci 66: 343-350

Hill AR, Cardaci M (2004) Denitrification and organic carbon availability in riparian wetland soils and subsurface sediments. Soil Sci Soc Am J 68:320-325

Höfle MG, Flavier S, Christen R, Bötel J, Labrenz M, Brettar I (2005) Retrieval of nearly complete 16S rRNA gene sequences from environmental DNA following 16S rRNA-based community fingerprinting. Environ Microbiol 7:670-675

> Holmer M, Storkholm P (2001) Sulphate reduction and sulphur cycling in lake sediments: a review. Freshw Biol 46: 431-451

Holmes RM, McClelland JW, Sigman DM, Fry B, Peterson BJ (1998) Measuring ${ }^{15} \mathrm{~N}-\mathrm{NH}_{4}{ }^{+}$in marine, estuarine and fresh waters: an adaptation of the ammonia diffusion method for samples with low ammonium concentrations. Mar Chem 60:235-243

Jones SE, Lennon JT (2009) Evidence for limited microbial transfer of methane in a planktonic food web. Aquat Microb Ecol 58:45-53

Jorgensen BB, Gallardo VA (1999) Thioploca spp: filamentous sulfur bacteria with nitrate vacuoles. FEMS Microbiol Ecol 28:301-313

> Joye SB, Hollibaugh JT (1995) Influence of sulfide inhibition of nitrification on nitrogen regeneration in sediments. Science 270:623-625

> Kamp A, Stief P, Schulz-Vogt HN (2006) Anaerobic sulfide oxidation with nitrate by a freshwater Beggiatoa enrichment culture. Appl Environ Microbiol 72:4755-4760

King GM, Klug MJ (1980) Sulfhydrolase activity in sediments of Wintergreen Lake, Kalamazoo County, Michigan. Appl Environ Microbiol 39:950-956

King GM, Klug MJ (1982) Comparative aspects of sulfur mineralization in sediments of a eutrophic lake basin. Appl Environ Microbiol 43:1406-1412

Labrenz M, Brettar I, Christen R, Flavier S, Bötel J, Höfle MG (2004) Development and application of a real-time PCR approach for quantification of uncultured bacteria in the central Baltic Sea. Appl Environ Microbiol 70: 4971-4979

Merrill AG, Zak DR (1992) Factors controlling denitrification rates in upland and swamp forests. Can J For Res 22: 1597-1604

Mulholland PJ, Helton AM, Poole GC, Hall RO and others (2008) Stream denitrification across biomes and its response to anthropogenic nitrate loading. Nature 452: 202-205 
Nielsen PH, de Muro MA, Nielsen JL (2000) Studies on the in situ physiology of Thiothrix spp. present in activated sludge. Environ Microbiol 2:389-398

Otte S, Kuenen JG, Nielsen LP, Paerl HW and others (1999) Nitrogen, carbon, and sulfur metabolism in natural Thioploca samples. Appl Environ Microbiol 65:3148-3157

Payne EK, Burgin AJ, Hamilton SK (2009) Sediment nitrate manipulation using porewater equilibrators reveals potential for $\mathrm{N}$ and $\mathrm{S}$ coupling in freshwaters. Aquat Microb Ecol 54:233-241

Porter ML, Engle AS, Kane TC, Kinkle BK (2009) Productivity-diversity relationships from chemolithoautotrophically based sulfidic karst systems. Int J Speleol 38:27-40

Rivett MO, Buss SR, Morgan P, Smith JWN, Bemment CD (2008) Nitrate attenuation in groundwater: a review of biogeochemical controlling processes. Water Res 42: 4215-4232

Saunders DL, Kalff J (2001) Nitrogen retention in wetlands, lakes and rivers. Hydrobiologia 443:205-212

Schubert CJ, Durisch-Kaiser E, Wehrli B, Thamdrup B, Lam P, Kuypers MMM (2006) Anaerobic ammonium oxidation in a tropical freshwater system (Lake Tanganyika). Environ Microbiol 8:1857-1863

Schulz HN, Brinkhoff T, Ferdelman TG, Marine MH, Teske A, Jorgensen BB (1999) Dense populations of a giant sulfur bacterium in Namibian shelf sediments. Science 284: 493-495

Scott JT, McCarthy MJ, Gardner WS, Doyle RD (2008) Denitrification, dissimilatory nitrate reduction to ammonium, and nitrogen fixation along a nitrate concentration gradient in a created freshwater wetland. Biogeochemistry 87:99-111

Seitzinger S, Harrison JA, Bohlke JK, Bouwman AF and others (2006) Denitrification across landscapes and waterscapes: a synthesis. Ecol Appl 16:2064-2090

Editorial responsibility: Tom Fenchel,

Helsingør, Denmark
Senga $Y$, Mochida $K$, Fukumori R, Okamoto N, Seike $Y$ (2006) $\mathrm{N}_{2} \mathrm{O}$ accumulation in estuarine and coastal sediments: the influence of $\mathrm{H}_{2} \mathrm{~S}$ on dissimilatory nitrate reduction. Estuar Coast Shelf Sci 67:231-238

Shao MF, Zhang T, Fang HHP (2010) Sulfur driven denitrification: diversity, biochemistry, and engineering applications. Appl Microbiol Biotechnol 88:1027-1042

Sher Y, Schneider K, Schwermer CU, van Rijn J (2008) Sulfide-induced nitrate reduction in the sludge of an anaerobic digester of a zero-discharge recirculating mariculture system. Water Res 42:4386-4392

- Sievert SM, Scott KA, Klotz MG, Chain PSG and others (2008) Genome of the epsilonproteobacterial chemolithoautotroph Sulfurimonas denitrificans. Appl Environ Microbiol 74:1145-1156

Vila X, Abella CA, Figueras JB, Hurley JP (1998) Vertical models of phototrophic bacterial distribution in the metalimnetic microbial communities of several freshwater North-American kettle lakes. FEMS Microbiol Ecol 25: 287-299

Wang FY, Chapman PM (1999) Biological implications of sulfide in sediment - a review focusing on sediment toxicity. Environ Toxicol Chem 18:2526-2532

Weber KA, Achenbach LA, Coates JD (2006) Microorganisms pumping iron: anaerobic microbial iron oxidation and reduction. Nat Rev Microbiol 4:752-764

Wetzel RG (2001) Limnology: lake and river ecosystems. Academic Press, San Diego, CA

Whitmire SL (2003) Anaerobic biogeochemical functions of Michigan wetlands and the influence of water source. $\mathrm{PhD}$ dissertation, Michigan State University, East Lansing, MI

Wolfinger R, Chang M 1999. Comparing the SAS GLM and MIXED procedures for repeated measures. SAS Institute, Cary, NC

Submitted: February 7, 2012; Accepted: May 9, 2012 Proofs received from author(s): July 2, 2012 